\title{
Pengembangan Permainan Bola Besar (Bolavoli) Berbasis Problem Based Learning Untuk Meningkatkan Minat Belajar Peserta Didik Putri
}

\author{
Susetya Kukuh Kurniawan ${ }^{1}$, Abdul Rachman ${ }^{2}$, Nanik Indahwati ${ }^{3}$ \\ Program Studi Pendidikan Olahraga, Program Pascasarja Universitas Negeri Surabaya \\ Email: Susetyakukuh@yahoo.co.id
}

\begin{abstract}
Abstrak. Setiap peserta didik berhak mendapatkan pendidikan yang baik, sebab pendidikan selalu berkembang dan meningkat setiap masanya. Pendidikan sendiri memiliki peran yang sangat vital bagi peserta didik salah satunya pendidikan jasmani olahraga kesehatan (PJOK). PJOK memiliki tujuan yaitu meningkatkan potensi fisik peserta didik, membudayakan sportivitas, dan budaya hidup sehat, maka dari itu perlu kita buat pembelajaran Pendidikan Jasmani Olahraga Kesehatan yang nyaman dan bisa tercapai tujuan-tujuan tersebut. Oleh karena itu dibutuhkan dalam penyusunan atau stategi pembelajran yang menarik agar tujuan tersbut tercapai. Maka dari itu, Penelitian ini bertujuan untuk menghasilkan perangkat pembelajaran pendidikan jasmani permainan bola besar berbasis Problem Based Learning(PBL) meningkatkan minat belajar peserta didik khususnya putri. Rancangan yang digunakan dalam penelitian ini adalah rancangan penelitian dan pengembangan (research \& development) mengacu pada model ADDIE singkatan dari Analysis, Design, Development, Implementation and Evaluations. Dalam penelitian ini karena bersamaan dengan masa pandemic maka diterpakan dengan penerpan elearning dalam upaya meningkatkan minat belajar peserta didik kususnya putri. Dalam penelitian ini terdapapan pengembang RPP, LKPD dan angket respon guru, anket minat belajar peserta didik dan ketrampilang pasing bawah bolavoli. Hasil pengembangan permaina bola besar berbasis problem based learning berbasis untuk meningkatkan minat belajar peserta didik putri adalah sebagai berikut pelaksanaan pembelajaran terlaksana baik dengan nilai $80,4 \%$, respon guru sangat baik dan pendapat sangat mendukung,keterampilan pasing bawah bolavoli peserta didik kuat mencapai $78,6 \%$ dan minat belajar kuat dengan nilai 75,05\%. Produk pengembangan permainan bola besar (bolavoli) berbasis problem based learning sangat baik bagi peserta didik putri untuk meningkatkan minat belajar.
\end{abstract}

\section{Kata kunci: Permainan Bola Besar, Problem Based Learning, Minat Belajar}

\section{PENDAHULUAN}

Pendidikan merupakan salah satu bekal untuk menjalani kehidupan dalam bermasyarakat sosial dan lain-lain, dinegara Indonesia sendiri jenjang pendidikan formal terbagi menjadi beberapa jenjang dari Sekolah Dasar sederajat, Sekolah Menengah Pertama sederajat, Sekolah Menengah Atas sederajat, dan Perguruan tinggi. Dalam undang-undangundang no 2 tahun 1989 pendidikan merupakan usaha sadar untuk menyiapkan peserta didik melalui kegiatan bimbingan dan latihan bagi perananya di masa akan datang. Maka dari itu pendidikan merupakan bagian penting dama kehidupan. Dalam pendidikan sendiri terdapat berbagai macam pembelajaran yang dapat di ambil manfaatnya. Pembelajaran sendiri merupakan suatu proses interaksi antara guru dengan murid yangg saling bertukar informasi, di setiap pembelajaran perlu interaksi yang baik agar tercapai pembelajran tersebut dari segi lingkungan, media dan lainya untuk menembah semangat dalam mengkuti kegiatan pembelajaran.

Pembelajaran sendiri juga ada beberapa bidang di dalamnya seperti salah satu pembelajaran Pendidikan jasmani olahraga kesehatan (PJOK) sendiri merupakan bidang wajib yang ada dan di ikuti oleh setiap pelajar di Indonesia. Pendidikan Jasmani Olahraga Kesehatan sendiri mempelajari kemampuan dalam bidang gerak atau keilmuaan yang berhubungan dengan kesehatan berolahraga, selain itu dalam pembelajaran Pendidikan Jasmani Olahraga Kesehatan kita bisa melihat banyak nilai-nilai yang di ambil seperti sportivitas, gotong 
royong, displin, kemudian selain nilai tersbut dalam pembelajaran Pendidikan Jasmani Olahraga Kesehatan kita dapat mengukur kemampuan potensi fisik peserta didik , keterampilan peserta didik secara lebih baik. Karena Pendidikan Jasmani Olahraga Kesehatan adalah bagian integral dari pendidikan keseluruhan yang mengutamakan aktivitas jasmani dan pembinaan hidup sehat untuk pertumbuhan dan perkembangan jasmani, mental, sosial, dan emosional yang serasi, selaras, dan seimbang (Kristiyandaru, 2012, p.33).

Pendidikan Jasmani Olaharaga Kesehatan sendiri memiliki tujuan yaitu meningkatkan potensi fisik peserta didik, membudayakan sportivitas, dan budaya hidup sehat, maka dari itu perlu kita buat pembelajaran Pendidikan Jasmanu Olahraga Kesehatan yang nyaman dan bisa tercapai tujuan-tujuan tersebut. karena dalam hal ini banyak pembelajaran yang belum sesuai dengan tujuan tersebut dan berdampak pembelajaran kurang menarik kepada peserta didik dan akirnya tujuan pembelajaran tidak tercapai kususnya pada peserta didik. Keterampilan dalam pendidikan jasmani sendiri merupakan suatu hal yang di perlukan dan dibutuhkan oleh setiap orang maka dari itu pembelajaran Pendidikan Jasmani Olahraga Kesehatan sangatlah diperlukan dan dirasa tepat masa sekolah merupakan masa dimana para peserta didik senang bermain, meski begitu tidak hanya anak usia dini saja bahkan remaja maupun dewasa juga membutuhkan bermain untuk mencukupi kebutuhan gerak sekaligus bersifat rekreasi (Hartati, dkk, 2012, p.1).

Keterampilan jasmani yang dijelaskan di atas sangtlah penting. Namun ada beberapa faktor-faktor yang menyebabkan keterampilan tersebut tidak tercapai, dari sarana prasana, dari kondisi peserta didik, apalagi peserta didik yang mayoritas perempuan, sangatlah kurang termotivasi dalam aktivitas jasmani, karena model pembelajaran yang kurang menarik, dan tidak ada motivasi dari peserta didik. Maka dari itu, sangat perlu kita mengembangkan motivasi peserta didik.

Kemampuan anak dapat di asah melalui permainan dalam Pendidikan Jasmani
Olahraga Kesehatan yang di kembangkan untuk memperbaiki motivasi belajar peserta didik. Dengan motivasi belajar yang baik diharapkan akan meningkatkan hasil belajar peserta didik. Namun permasalahan yang terjadi di sekolah khusunya SMKN 1 Bojonegoro yang mayoritas peserta didiknya perempuan adalah karena kurang baiknya kemauan motivasi untuk mengikuti pembelajaran Pendidikan Jasmani Olahraga dan Kesehatan , maka dari itu perlu perbaikan dari segi materi pembelajaran model dan media pembelajaran, dan motivasi peserta didik.

Motivasi dapat dikatakan sebagai salah satu hal penting saat pembelajaran berlangsung, karena saat peserta didik mengikuti proses belajar mengajar diharapkan peserta didik mengikuti dengan antusias dan semangat terhadap materi pembelajaran. Menurut Maksum (2011, p.71) dilihat dari sumbernya, motivasi seseorang bisa intrinsik dan ekstrinsik, yang dimaksud motivasi intrinsik yaitu motivasi yang timbul dari dalam diri sendiri tanpa ada pengaruh dari luar, seperti saat siswa memotivasi dirinya sendiri untuk bisa melakukan suatu tugas gerak. Sedangkan motivasi ekstrinsik yaitu motivasi yang berasal dari luar, seperti saat siswa berhasil melakukan tugas gerak dengan baik maka akan diberi hadiah oleh guru. Maka dari itu dalam suatu pembelajaran dibutuhkan suatu metode yang baik agar dapat meningkatkan motivasi peserta didik untuk mengikuti pembelajaran.

Kesimpulan dari permasalahan di atas dan dengan keinginan membantu, maka peneliti ingin mengembangkan sebuah model pembelajaran permainan bola besar berbasis PBL untuk meningkatkan minat belajar peserta didik, khususnya bolavoli. Untuk itu diharapkan dengan metode permainan bola besar yang akan digunakan dalam penelitian ini dapat menambah wawasan serta dapat mempermudah membantu meningkatkan hasil belajar peserta didik.

\section{METODE}

Penelitian ini dikategorikan ke dalam jenis penelitian pengembangan (research and development), penelitian ini merupakan 
penelitian yang akan menghasilkan produk yang bertujuan untuk membuat model pembelajaran baru dan dapat diimplentasikan di sekolah untuk menbantu meningkatkan ketrampilan dan kotrivasi peserta didik di Sekolah Menengah Kejuruan (SMK). Pengembangan model ini mengacu pada Model ADDIE. Dalam pemilihan model ADDIE ini langkah yang sistematis dalam setiap tahapan menjadi dasar pemilihan model tersebut dimana pada setiap langkah memungkinkan untuk dilakukannya evaluasi jika masih ada kekurangan untuk mendapatkan produk pengembangan yang diinginkan. Banyak bentuk pengembangan yang menggnakan model ADDIE (Analyze, Design, Development, Implementation, Evaluation) diantaranya strategi pembelajaran, model pembelajaran, metode pembelajaran, bahan ajar dan media.

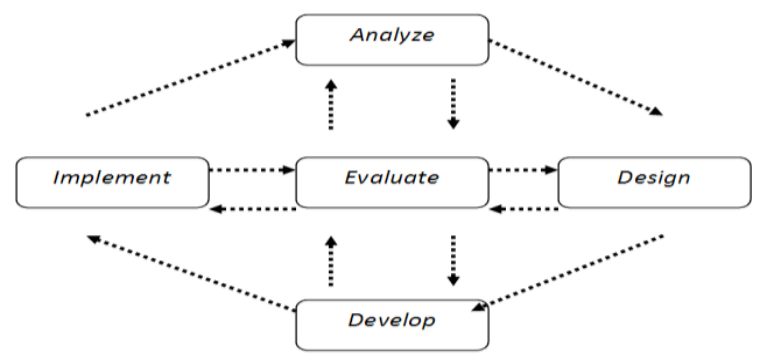

Gambar 1. Langkah-Langkah Pendekatan ADDIE Untuk Pengembangan Produk Model Pembelajaran (Tegeh, 2014: 42).

Teknik analisis data yang digunakan adalah teknik analisis dengan menggunakan metode kombinasi sequential mixed methods, karena ada dua tahap kegiatan yang berurutan. Kegiatan tahap 1 adalah melakukan research untuk menghasilkan rancangan produk dan kegiatan tahap 2 adalah melakukan development untuk memproduk rancangan kemudian mengujinya (Sugiyono, 2016: 382). Urutan analisisnya sebagai berikut.

\section{Analisis Tahap 1 (Analisis Rancangan Produk)}

Validitas perangkat pembelajaran yang dikembangkan ditentukan berdasarkan hasil penilaian oleh pakar/ahli/validator. Data hasil penilaian dianalisis secara deskriptif dengan kriteria sangat valid, cukupvalid, kurang valid, dan tidak valid. Rumus menghitung validitas perangkat adalah sebagai berikut:

$$
V=\frac{\sum T S h}{\sum T S e} \mathrm{x} 100 \% V
$$

Keterangan:

$$
\begin{aligned}
\mathrm{V} & =\text { Validitas } \\
\text { Tsh } & =\text { Total skor maksimal yang } \\
& \text { diharapkan } \\
\text { Tse } & =\text { Total skor Empiris }
\end{aligned}
$$

Tabel 1. Kriteria Pengkategorian Penilaian

\begin{tabular}{|l|l|}
\hline Kriteria validasi & Kategori Penilaian \\
\hline $85,01 \%-100 \%$ & Sangat valid \\
\hline $70,01 \%-85 \%$ & Cukup valid \\
\hline $50,01 \%-70 \%$ & Kurang valid \\
\hline $01,01 \%-50 \%$ & Tidak valid \\
\hline $\begin{array}{l}\text { Analisis Tahap 2 } \\
\text { Pengujian) }\end{array}$ & (Pengembangan dan \\
\hline
\end{tabular}

a. Keterlaksanaan RPP

Pengamatan kepraktisan RPP dilakukan oleh dua pengamat yang sudah dilatih memberikan penilaian dengan tepat pada instrumen yang telah disediakan. Kriteria fase pembelajaran yang dinilai dengan memberikan checklist pada kolom keterlaksanaan (4: sangat baik, 3: baik, 2: kurang baik, 1: tidak baik). Teknik analisis data secara deskriptif kualitatif dengan teknik persentase adalah sebagai berikut:

$$
P=\frac{\sum A}{\sum N} \mathrm{x} 100 \%
$$

Keterangan:

$$
\begin{array}{ll}
\mathrm{P} & =\text { persentase keterlaksanaan RPP } \\
\sum \mathrm{A} & =\text { jumlah aspek yang terlaksana } \\
\sum \mathrm{N} & \begin{array}{l}
\text { = jumlah keseluruhan aspek yang } \\
\text { diamat }
\end{array}
\end{array}
$$

Tabel 2. Kriteria Penelian RPP

\begin{tabular}{|l|l|}
\hline \multicolumn{1}{|c|}{ Interval } & Kategori Penilaian \\
\hline $75 \% \leq \mathrm{P} \leq 100 \%$ & $\begin{array}{l}\text { Terlaksana sangat } \\
\text { baik }\end{array}$ \\
\hline $50 \% \leq \mathrm{P}<75 \%$ & Terlaksana Baik \\
\hline $25 \% \leq \mathrm{P}<50 \%$ & $\begin{array}{l}\text { Terlaksana Kurang } \\
\text { Baik }\end{array}$ \\
\hline $0 \% \leq \mathrm{P}<25 \%$ & Tidak Terlaksana \\
\hline
\end{tabular}

b. Analisis Respon Guru

Data respon pengguna terhadap kegiatan pembelajaran dianalisis secara deskriptif kualitatif. Data respon pengguna 
digunakan untuk menjawab pertanyaan peneliti tentang bagaimana respon pengguna terhadap perangkat pembelajaran yang dikembangkan dengan rumus persentase sebagai berikut:

$$
P=\frac{f}{N} \times 100 \%
$$

Keterangan:

$$
\begin{array}{ll}
\mathrm{P} & =\text { Persentase } \\
f & =\text { Jumlah jawaban responden } \\
N & =\text { Jumlah responden }
\end{array}
$$

Tabel 3. Kriteria respon

\begin{tabular}{|l|l|}
\hline \multicolumn{1}{|c|}{ Interval } & \multicolumn{1}{c|}{ Kategori Penilaian } \\
\hline $0 \%-20 \%$ & Sangat lemah \\
\hline $21 \%-40 \%$ & Lemah \\
\hline $41 \%-60 \%$ & Cukup \\
\hline $61 \%-80 \%$ & Kuat \\
\hline $81 \%-100 \%$ & Sangat kuat \\
\hline
\end{tabular}

c. Analisis keterampilan pasing bawah dan minat belajar

keterampilan pasing bawah peserta didik adalah kemampuan peseta didik melakukan keterampilan pasing bawah tentang proses lempar tangkap dan pasing bawah dalam permainan bola besar. Adapun proses penilaian hasil belajar kemampuan keterampilan pasing bawah peserta didik dapat dilihat dari pendiskripsian hasil persentase sebagai berikut:

$$
P=\frac{f}{N} \times 100 \%
$$

$$
\begin{aligned}
& \text { Keterangan: } \\
& \mathrm{P}=\text { Persentase } \\
& f=\text { Jumlah jawaban responden } \\
& N=\text { Jumlah responden }
\end{aligned}
$$

Tabel 4. Kriteria keterampilan pasing bawah

\begin{tabular}{|l|l|}
\hline \multicolumn{1}{|c|}{ Interval } & Kategori Penilaian \\
\hline $0 \%-20 \%$ & Sangat lemah \\
\hline $21 \%-40 \%$ & Lemah \\
\hline $41 \%-60 \%$ & Cukup \\
\hline $61 \%-80 \%$ & Kuat \\
\hline $81 \%-100 \%$ & Sangat kuat \\
\hline
\end{tabular}

Adapun proses penilaian motivasi peserta didik menggunakan angket dengan menggunakan perhitungan skala likert dengan kriteria sangat setuju, setuju, tidak berpendapat, tidak setuju, dan sangat tidak setuju.

\section{HASIL DAN PEMBAHASAN}

Dalam tahap pengembangan ini, kerangka yang masih konseptual direalisasikan menjadi produk yang siap diimplementasikan. Tahap pengembangan adalah untuk menghasilkan perangkat pembelajaran yang memenuhi syarat valid dan sahih (reliable). Perangkat pembelajaran yang dikembangkan yaitu Rencana Pelaksanaan Pembelajaran (RPP) yang digunakan setelah validasi lembar observasi keterampilan komunikasi dan kemampuan pasing bawah. Perangkat pembelajaran sebelum di ujicobakan direvisi sesuai saran ahli.

Rencana Pelaksanaan Pembelajaran

\begin{tabular}{|c|c|c|c|}
\hline No & Aspek yang dinilai & Validator & Kriteria \\
\hline 1 & $\begin{array}{l}\text { Kejelasan perumusan tujuan pembelajaran (mencakup } \\
\text { kompetensi inti (KI): KI-3, dan KI-4) }\end{array}$ & 3 & Cukup \\
\hline 2 & $\begin{array}{l}\text { Pemilihan materi ajar (sesuai dengan tujuan dan } \\
\text { karakteristik peserta didik) }\end{array}$ & 4 & Baik \\
\hline 3 & $\begin{array}{l}\text { Pengorganisasian materi ajar (keruntutan, sistematika } \\
\text { materi, dan kesesuaian dengan alokasi waktu) }\end{array}$ & 4 & Baik \\
\hline 4 & $\begin{array}{l}\text { Pemilihan sumber/media pembelajaran (sesuai dengan } \\
\text { tujuan, materi, dan karakteristik peserta didik) }\end{array}$ & 4 & Baik \\
\hline 5 & $\begin{array}{l}\text { Langkah-langkah kegiatan pembelajaran meliputi } \\
\text { kegiatan awal, inti, dan penutup. }\end{array}$ & 4 & Baik \\
\hline 6 & $\begin{array}{l}\text { Skenario pembelajaran mencerminkan metode saintifik } \\
\text { (mengamati, menanya, menalar, mencoba, dan } \\
\text { membuat jejaring) }\end{array}$ & 4 & Baik \\
\hline 7 & $\begin{array}{l}\text { Kesesuaian teknik penilaian dengan indikator/tujuan } \\
\text { pembelajaran, misal: tes tulis, kinerja, sikap, dan } \\
\text { portofolio, diutamakan penilaian bersifat otentik. }\end{array}$ & 4 & Baik \\
\hline 8 & $\begin{array}{l}\text { Kelengkapan instrumen penilaian (soal, kunci, } \\
\text { pedoman penskoran) }\end{array}$ & 4 & Baik \\
\hline & \begin{tabular}{|l} 
Skor Total \\
\end{tabular} & 31 & Baik \\
\hline
\end{tabular}
(RPP) digunakan guru sebagai pedoman pelaksanaan kegiatan belajar mengajar yang berisikan skenario penyampaian materi pembelajaran RPP yang digunakan dalam penelitian ini dilaksanakan dalam satu kali pertemuan.Hasil penilaian terhadap RPP dapat dilihat lebih rinci pada tabel berikut.

Tabel 5. Hasil Validasi RPP

Berdasarkan Tabel 5 dapat diketahui bahwa RPP yang telah dikembangkan peneliti dapat digunakan sebagai perangkat pembelajaran dengan sedikit revisi, dimana rata-rata skor penilaian validator sebesar 31 atau $77,5 \%$ dalam kriteria pengkategorian penilaian termasuk dalam kriteria cukup valid dan layak digunakan sebagai perangkat pembelajaran.

Dalam penerapan pembealajran tersebut terdapat hasil penerapan gerak dasar pasing bawah dalam bolavoli dimana kriteria 
keuntasan peserta didik yang tuntas sebesar 30 peserta didik atau sebesar $83 \%$ dan yang belum tuntas sebanyak 6 peserta didik atau sebesar $17 \%$. Dan rata-rata pengusaan peserta didik sudah mencapai 78, 6 persen dalam pelaksanaan gerak dasar pasing bawah bolavoli maka dari sini dapat dilihat kefektifan penerpan pembelajaran dalam ketrampilan pasing bawah valid.

Hasil validasi sebanyak 20 minat belajar peserta didik jika dihitung maka diperoleh hasil $80 \%$, sehingga insturmen dikatakan valid dan dapat di ujicobakan. Setelah insturmen di ujikan terdapat hasil data yang telah di ujikan, yaitu skor dari instumen minat belajar peserta didik dengan skor total 131.33 dan skor rata-rata minat belajar peserta didik sebesar 75,05\%, maka dari ini dari sini dapat dilihat minat belajar peserta didik sebesar 75,05\%.

Pengamatan pelaksanaan RPP pendidikan jasmani permainan bola besar berbasis Problem Based Learning (PBL) bagi peserta didik Putri SMKN 1 Bojoneogoro untuk mengajarkan keterampilan Minat Belajar dan keterampilan pasing bawah peserta didik putri, dilakukan oleh observer atau pengamat. Kegiatan pengamatan dilakukan dengan menggunakan lembar pengamatan pelaksanaan RPP yang dirancang seperti model pembelajaran berdasarkan masalah didapatkan hasil pelaksanaan RPP di sekolah I dengan nilai 45 berarti bahwa jika dihitung dengan nilai maksimal maka didapatkan 80,4\%. Jadi, keterlaksanaan RPP jika dilihat dari hasil tersebut maka dapat dikategorikan terlaksana dengan sangat baik berdasarkan tabel pengkategorian teoritis perangkat $(70,01 \%-85 \%)$ yang berarti Baik (Sa'dun. 2015: 155).

Respon Guru terhadap perangkat pembelajaran pendidikan jasmani permainan bola besar berbasis Problem Based Learning (PBL) untuk meningkatkan minat belajar ini dilakukan oleh seorang guru langsung dengan menggunakan lembar respon pengguna. Respon pengguna rata-rata sangat baik untuk respon RPP dan LKPD sangat baik dengan pencapain 85,5. Sedangkan untuk pendapat pengguna dalam penggunaan RPP, LKPD mendukung (Tabel 6).
Tabel 6. Lembar hasil respon pengguna

\begin{tabular}{|l|c|c|}
\hline \multirow{2}{*}{ Aspek Yang Direspon } & \multicolumn{2}{|c|}{ Respon Pengguna } \\
\cline { 2 - 3 } & Nilai & Pendapat \\
\hline $\begin{array}{l}\text { Bagaimanakah penilaian Bapak/lbu } \\
\text { terhadap RPP }\end{array}$ & Sangat baik & Mendukung \\
\hline Instrumen Penilaian Hasil Belajar & Sangat baik & Mendukung \\
\hline \multicolumn{2}{|c|}{ Pelaksanaan penerapan perangkat } \\
\hline
\end{tabular}

pembelajaran secara umum berlngsung dengan baik namun ada beberapa poin penting yang perlu di evaluasi. Dampak pengembangan model pembelajaran secara kritis bisa dilihat dari penilaian pelaksanaan pembelajaran yang dilakukan. Berdasarkan rekapitulasi penilaian pelaksanaan pembelajaran dijelaskan bahwa pengembangan permainan bola besar berbasis PBL pembelajaran pendidikan jasmani terlaksana sangat baik. Dikuatkan juga oleh respon guru terhadap pengembangan perangkat pembelajaran pendidikan jasmani Meningkatkan Minat Belajar. Ketercapaian pengembangan perangkat pembelajaran antara lain, RPP yang telah dirancang divalidasi oleh pakar mendapatkan penilaian valid. Selanjutnya, untuk lembar observasi Minat Belajar digunakan setelah dilakukan validasi orang yang berkompeten pada bidangnya. Setelah pelaksanaan, terdapat beberapa saran dari pihak-pihak yang terlibat, antara lain: Pelaksanaan evaluasi ahli memerlukan waktu yang panjang. Peneliti harus menyesuaikan waktu yang dimiliki oleh masing-masing para ahli untuk meluangkan waktunya kepada peneliti. Karena hal ini disesuaikan dengan jadwal pelajaran. Materi yang dikembangkan hanya satu sub materi yaitu pasing bawah. Pengambilan data dikhususkan hanya pada SMKN 1 Bojonegoro saja. Peserta didik terbatas hanya satu kelas.

Peneliti meyakini bahwa keberhasilan guru dalam mengajar didalam kelas salah satunya ditentukan oleh persiapan guru melakukan kegiatan belajar mengajar. Persiapan mengajar guru dituangkan di dalam Rencana Pelaksanaan Pembelajaran (RPP) yang memuat skenario pembelajaran dengan model pembelajaran yang dipilih, materi yang disampaikan, media pembelajaran dan, alokasi waktu pembelajaran. Persiapan yang 
baik dengan perangkat pembelajaran yang baik pula akan menjadikan kegiatan belajar mengajar berlangsung dengan baik sehingga memudahkan untuk mencapai tujuan pembelajaran.

Perangkat pembelajaran yang telah dikembangkan dalam penelitian ini adalah implementasi pembelajaran pendidikan jasmani permainan bola besar berbasis Problem Based Learning (PBL) peserta didik putri untuk meningkatkan minat belajar. Perangkat pembelajaran yang dikembangkan adalah RPP permainan bola besar, instumen minat belajar angket respon pengguna. RPP merupakan pedoman bagi guru dalam melaksanakan kegiatan belajar mengajar di kelas. RPP yang dikembangkan dalam penelitian ini adalah RPP untuk materi bolavoli. Kompetensi dasar yang telah dipilih kemudian dijabarkan menjadi beberapa indikator dan selanjutnya dijadikan pedoman untuk menentukan tujuan pembelajaran. Analisis kompetensi dasar juga meliputi model pembelajaran yang dipilih. Dalam hal ini peneliti memilih pembelajaran dengan model Problem Based Learning, dengan pertimbangan: 1) siswa mampu memproses dan mengingat informasi yang telah diperoleh, 2) menarik minat siswa, 3) memberikan aktivitas pasing bawah siswa, 4) menambah minat belajar peserta didik saat pembelajaran. RPP yang telah dirancang divalidasi oleh pakar. Hasil validasi RPP menunjukkan bahwa RPP pada aspek format mendapatkan penilaian valid. Hal ini menunjukkan RPP yang dikembangkan sudah sesuai indikator pembelajaran yang dicapai siswa, serta sesuai dengan model yang akan digunakan dalam pembelajaran. Berdasarkan masukan dari validator, RPP yang telah dirancang peneliti diperbaiki dan diperhatikan saat pembelajaran. Perangkat pembelajaran yang telah divalidasi oleh para validator yang memiliki keahlian dibidangnya, selanjutnya dapat dilakukan perbaikan sesuai masukan yang diberikan. Catatan-catatan revisi, pada RPP kegiatan pembelajarannya lebih diperinci, kejelasan tujuan . dan pada intrumen minat belajar ada beberpa poin yang muatannya hampir sama.
Penilaian angket respon guru yang diisi oleh 1 guru di 1 sekolah. Dari pertanyaan tersebut dipraktiskan menjadi dua pokok penilain, RPP dan minat belajar. Berdasarkan rekapitulasi angket respon guru di atas dijelaskan bahwa respon guru terhadap pengembangan perangkat pembelajaran pendidikan jasmani olahraga kesehatan permainan bola besar untuk mengajarkan keterampilan pasing bawah sangat baik dan mendukung. Lembar observasi keterampilan pasing bawah terdapat 3 pelaksanaan gerak yang diisi oleh observer. Berdasarkan rekapitulasi lembar observasi keterampilan pasing bawah di atas dijelaskan bahwa pengembangan perangkat pembelajaran penjas untuk keterampilan pasing bawah baik. Hal ini dibuktikan pada hasil penerpan di sekolah diperoleh nilai total respon guru sebesar 78,6\% dengan kategori sangat baik. Kemampuan pasing bawah peserta didik dapat dilihat dari anak mendapatkan masalah dalam materi "bolavoli" ini menunjukan peserta didik melakukan kegiatan melakukan pasing bawah bolavoli. Semua peserta didik diharapkan aktif dalam kegiatan pasing bawah bolavoli. Hal tersebut menunjukkan bahwa model pembelajaran yang digunakan dalam proses pembelajaran ini dapat mengajarkan kemampuan pasing bawah peserta didik. Lembar observasi keterampilan minat belajar terdapat 35 pertanyaan yang diisi oleh observer. Berdasarkan rekapitulasi lembar observasi minat belajar dijelaskan bahwa pengembangan perangkat pembelajaran penjas dalam hal minat belajar cukup kuat. Minat Belajar sangat berperan dalam diri peserta didik, hal ini sangat terlihat saat anak pada pembelajran sangat beratusias dan aktif dalam pelaksanaan pembelajran , dan berdiskusi dengan kelompok walaupun pada pelaksanaan pembelajran secara daring. Hal tersebut menunjukkan bahwa model pembelajaran yang diterapkan dalam proses pembelajaran ini dapat meningkatkan minat bbelajar pesera didik. Berdasarkan hasil yang dijelaskan diatas dapat produk pengembangan dapat digunakan karena dua instrumen memberikan kategori yang kuat. 
Berdasarkan hasil penelitian tentang pengembangan perangkat pembelajaran pendidikan jasmani permainan bola besar (bolavoli) berbasis PBL (problem based learning) untuk meningkatkan minat belajar maka dapat diambil kesimpulan sebagai berikut:

1. Rencana Pelaksanaan Pengajaran (RPP) menggunakan permainan bola besar berbasis model pembelajaran berbasis masalah bagi peserta didik putri dalam mata pelajaran PJOK layak untuk diimplementasikan secara teoritis dan empiris. RPP yang dikembangkan memenuhi syarat validitas dan berkualitas dengan nilai $80,4 \%$ kategori terlaksana sangat baik.

2. Model pembelajaran berbasis masalah bagi peseta didik putri dalam mata pelajaran penjas dapat meningkatkan efektifitas minat belajar sebesar 75,05\% dan ketrampilan pasing bawah sebesar dapat dibuktikan dengan nilai sebesar $78,6 \%$ kriteria sangat kuat.

3. Respon guru sangatlah baik terhadap model pembelajaran berbasis masalah kusus peserta didik putri dengan permaian bolavoli pasing bawah dengan skor 85,5 $\%$ sangat baik dan mendukung.

\section{DAFTAR PUSTAKA}

Ahmadi, N. 2007. Panduan Olahraga Bola Voli. Solo: Era pustaka utama.

Akbar, Sa'dun. (2015). Instrumen Perangkat Pembelajaran. Bandung: PT. Remaja Rosda Karya.

Ardiansyah, I. 2013. Eksplorasi Pola Komunikasi dalam Diskusi Menggunakan Moddle pada Perkuliahan Simulasi Pembelajaran Kimia, Universitas Pendidikan Indonesia, Bandung-Indonesia.

Borg. W.R \& Gall, M.D, (1983) Educational Research an Introduction. New Yowk: Longman

Buku Siswa Kurikulum 2013, (2013). Pendidikan Jasmani Olahraga dan Kesehatan. Jakarta: Permendikbud.

Demir, K. 2011. Teachers Intrinsic And Extrinsic motivation As Predictors
Of Student Engagement. New World Science Academy. 6(2). 1397-1409.

Dieter Beutelstahl. (2007). Belajar Bermain Bola Volley. Bandung: Pionir Jaya

FIVB. 2013. Official Volleyball Rules. Lausanne: FEDERATION INTENATIONAL VOLLEYBALL.

Hamalik, O. 2010. Psikologi Belajar \& Mengajar.Bandung. Sinar Baru algesindo.

Hartati, S.C.Y., Priambodo, A \& Kristiyandaru, A. 2012. Permainan Kecil. Surabaya. Wineka Media.

Jaakkola, T., Jhon Wang, C. K., Soini, M., Liukkonen, J., (2015). Students' Perceptions of Motivational Climate and Enjoyment in Finnish Physical Education: A Latent Profile Analysis. Sports Science and Medicine, 2(14), 477-483.

Kemdikbud. (2013). Modul Pelatihan Implementasi Kurikulum 2013. Kementrian Pendidikan dan Kebudayaan

Kristiyandaru, A. 2012. Manajemen Pendidikan Jasmani dan Olahraga. Surabaya: Unesa University Press.

L. Tjokro, Sutanto. 2009. Presentasi yang Mencekam. Jakarta: Elex Media Komputindo.

Lutan, Rusli. (2006) Asas-Asas Pendidikan Jasmani. Jakarta: Departemen Pendidikan Nasional

Mahardika, M. S (2014). Evaluasi Pengajaran. Surabaya: Unesa University Press

Maksum, A. (2012). Metodologi Penelitian Dalam Olahraga. Surabaya: Unesa University Press.

Maksum, A. 2011. Psikologi Olahraga Teori dan Aplikasi. Surabaya. Unesa University Press.

Mutohir. T.C., \& Maksum. A. (2006). Sport Development Index. Jakarta: $\mathrm{Pt}$ Indeks.

Nursalam dan Ferry Efendi. 2008. Pendidikan dalam Keperawatan. Jakarta: Salemba Medika.

Rahayu, E.T. 2013. Strategi Pembelajaran Pendidikan Jasmani. Bandung: Alfabeta. 
Ratumanan, Gerson, T. \& Laurens, T. (2015). Penilaian Hasil Belajar Pada Tingkat Satuan Pendidikan. Surabaya: Unesa University Press.

Ullah, M. I., Sagheer, A., Sattar, T., \& Khan, S. 2013. Factors Influencing Students Motivation to Learn in Bahauddin Zakariya University, Multan (Pakistan). International Journal of Human Resource Studies. 3(2). 90-108.

Uno, H. B. 2013. Teori Motivasi \& Pengukurannya. Gorontalo: Bumi Aksara.

William, K. C \& William C. C. 2011. Five Key Ingredients for Improving Student Motivasion. Research in Higher educatin journal. 12, 1-23.

Winarno, M.E.. 2013. Teknik Dasar Bermain

Bola Voli. Malang: Universitas Negeri Malang 